\title{
Some Biological Aspects of Cultured Ompok pabda (Hamilton, 1822) Collected from A Local Fish Farm in Mymensingh, Bangladesh
}

\author{
Dulon Roy ${ }^{1, *}\left(\mathbb{D}\right.$, Ashish Kumer Sarker ${ }^{1}$, Abu Musa Mohammad Khairul Abedin ${ }^{1}$, \\ Smita Sarker ${ }^{2}$, Kazi Nahida Begum ${ }^{3}$, Gulshan Ara Latifa ${ }^{4}$
}

\author{
${ }^{1}$ Jagannath University, Faculty of Life and Earth Sciences, Department of Zoology, Dhaka-1100, Bangladesh. \\ 2Jagannath University, Faculty of Sciences, Department of Statistics, Dhaka-1100, Bangladesh. \\ ${ }^{3}$ Jagannath University, Faculty of Life and Earth Sciences, Department of Botany, Dhaka-1100, Bangladesh. \\ ${ }^{4}$ University of Dhaka, Faculty of Biological Sciences, Department of Zoology, Dhaka-1000, Bangladesh.
}

\section{How to cite}

Roy, D., Sarker, A.K., Abedin, A.M.M.K., Sarker, S., Begum, K.N., Latifa, G.A. (2021). Some Biological Aspects of Cultured Ompok pabda (Hamilton, 1822) Collected from A Local Fish Farm in Mymensingh, Bangladesh. Aquaculture Studies, 21, 149-159. http://doi.org/10.4194/2618-6381-v21_4_02

\section{Article History}

Received 28 December 2020

Accepted 24 April 2021

First Online 29 April 2021

\section{Corresponding Author}

Tel.: +8801911932492

E-mail: dulonroy@gmail.com

\section{Keywords}

Biology

Ompok

Growth

Induced breeding

Fecundity

\begin{abstract}
An experiment was conducted to observe some biological aspects including growth, sex ratio, gonadal maturity, artificial insemination, fecundity, fertilization, hatching and larval development of $O$. pabda in a private hatchery. Total weight of the sampled fish varied from $1.60 \pm 0.43$ to $111.12 \pm 6.83 \mathrm{~g}$ and length varied from $3.57 \pm 0.65$ to $21.22 \pm 1.84 \mathrm{~cm}$ with the SGR $2.85 \pm 0.18$ and ADG $0.73 \pm 0.05$. The length and weight of the fish had a strong correlation $\left(r^{2}=0.966\right)$. Female dominance over male has been observed in the species. The male to female ratio was $1: 1.48$. Females were $16.8 \mathrm{~cm}$ in length at first maturity, while males were $16.6 \mathrm{~cm}$ in length. The GSI of female were ranged from 2.93 to 4.77 with the mean of $3.77 \pm 0.60$ during the study period. The fecundity of $O$. pabda was ranged from 5675 to 19626 with the mean of $12503 \pm 4192$ for the corresponding length $21.23 \pm 1.71$, body weight $111.12 \pm 7.6$ and gonad weight $4.19 \pm 0.87$. Fertilization rate, hatching rate and larval development observed during the experiment. Scattered diagram for length-weight, fecundity-length, fecunditybody weight and fecundity-gonad weight relationship shows a perfect correlation both arithmetically and logarithmically.
\end{abstract}

\section{Introduction}

In Bangladesh, livelihoods of rural and poor people totally depend on freshwater fisheries which is very significant (Mazid, 2002). Fish farming practices have the ability to attain self-reliance in the food sector and to minimize scarcity in Bangladesh (Al-Amin et al., 2012).

Fish biology is indispensable for sustainable development and protection of fish biodiversity (Solomon et al., 2012). Reproductive potential of a population is one of the basic elements to entitle the entities of that population regarding their gonadal conditions (Jhingran and Verma, 1972). To understand reproductive biology of fish is important for estimating the viable potentialities of its stock, life history, culture practice and management of its fishery (Cortes, 2000; Soofiani et al., 2006; Dopeikar et al., 2015).

Ompok pabda (Hamilton-Bouchanan, 1822) is an economically important species with high market demand in Bangladesh as well as in other South East Asian countries (Talwar and Jhingran, 1991). O. pabda is a native fishes of Bangladesh, locally known as pabda, a small freshwater catfish classified under the family Siluridae of the order Siluriformes (Siddiqua et al., 2000). It is distributed widely in Bangladesh, India, Pakistan, Myanmar and Afghanistan (Jayaram, 2009; Mukhopadhyay and Ghosh, 2007); and is frequently found in normal water bodies like flood plains, lakes, 
streams and rivers (Talwar and Jhingran, 1991; Hussain, 2006; Chakrabarti et al., 2012). Some of the researcher (Chakrabarti et al., 2012; Parameswaram et al., 1971) have documented it as a carnivorous fish while some others (Shafi and Quddus, 2001) have recognized it's an omnivorous fish. It has high fondness as a table fish due to tasteful and high dietary value (Datta et al., 2003; Chakrabarty et al., 2006, 2007; Chakrabarti et al., 2009; Banik et al., 2012; Purkayastha et al., 2012); and its suitability as an attractive fish among the fish lovers has recently been conveyed (Gupta and Banarjee, 2008, 2013). The breeding season of $O$. pabda have reported May to July (Siddiqui and Choudhury, 1996) while Akhteruzzaman et al. (1993) and Chakraborty et al. (2010) have reported May to August. Due to indiscriminate fishing, habitat degradation, widespread use of pesticides and insecticides in agricultural fields, and the depletion of spawning grounds for this fish species, the amount of fish in the natural catch has decreased in recent years (Chakrabarti et al., 2012; Chakrabarty et al., 2006, 2007; Purkayastha et al., 2012). The reasons behind the alternation of this fish species is also resulting from the lack of proper knowledge on its domestication in culture system, breeding and farming technique and proper management (Chakrabarty et al., 2006). Due to loss of habitat in nature, it has already been enlisted as an endangered species both in India (CAMP, 1998) and Bangladesh (IUCN, 2000). IUCN has been categorize this fish species near threatened of the Red List of Threatened Species. Limited studies have been conducted on food, feeding habit and reproductive biology of $O$. pabda; but published paper on these aspects so far is not available in Bangladesh. The present study aims to combine the already available information on its biology including reproduction, larval development, growth, feeding, culture system etc. which can be considered for its conservation and useful for fisheries and aquaculture production in future.

\section{Materials and Methods}

\section{Study Area and Period}

The study was conducted in the "Deshbandhu Matsya Hatchery and Nursury" (Shombhugonj, Mymensingh) from March to July, 2019 (Fig 1).

\section{Brood Fish Collection}

Required number of male and female broods in good physical condition were isolated (Table 1) in the prepared brood ponds. Male and female of $O$. pabda can be easily categorized observing the sex characteristics or behavioral signs which develop throughout the breeding season.

\section{Conditioning of Brood Fish}

Selected brood fish were kept in tank for about 6 hours for conditioning prior to injection with $\mathrm{SGnRHa}$ extract. Fishes were handled and carried very carefully to eliminate possible injury and minor infection. Males and females fish were reserved in different tanks and constant water flow was continued to maintain adequate ventilation.

\section{Sex Ratio}

The sex ratio was calculated monthly from the proportion or ratio of females to males. Sex ratio was estimated according to Pena-Mendoza et al., 2015. The formula is

$$
\text { Sex ratio }=\frac{\text { Number of males }}{\text { Number of females }}
$$

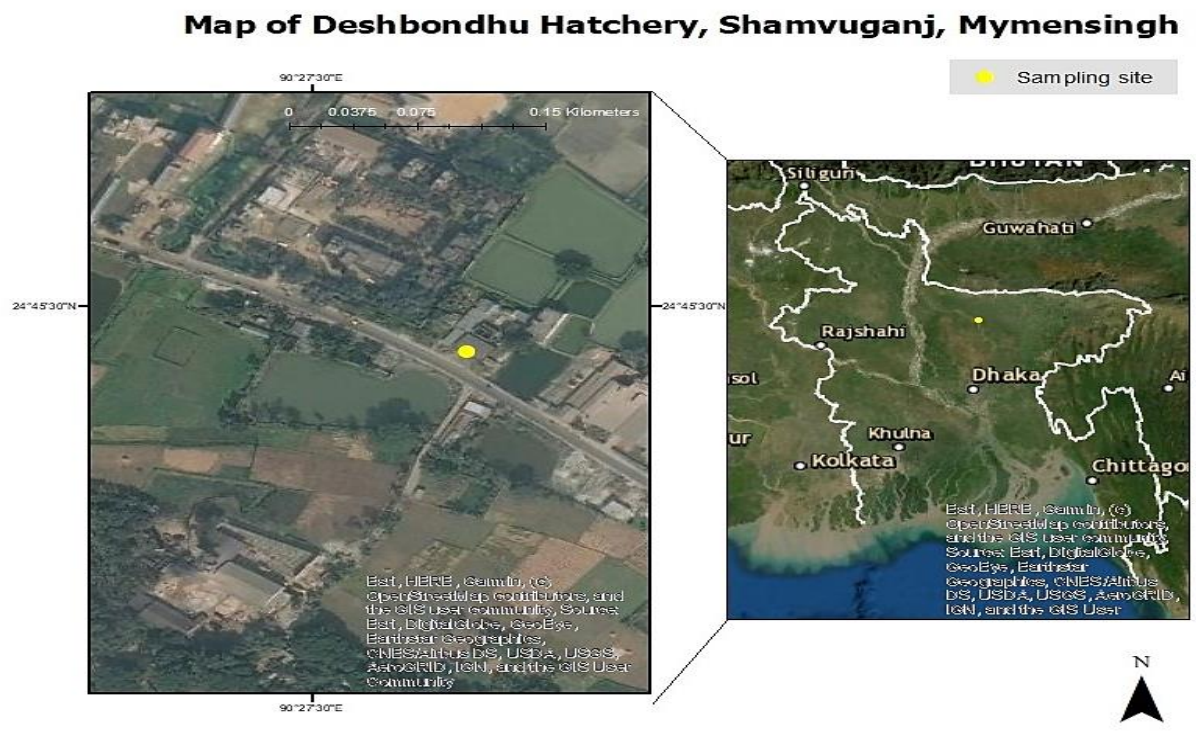

Figure 1. GIS Map of Study Area 
Table 1. Selection criteria of male and female mature breeders of $O$. pabda.

\begin{tabular}{lcr}
\hline Criteria & Male & Female \\
\hline Size & Smaller in size & Comparatively larger in size \\
Abdomen & Abdomen normal, not bulky like female & Abdomen soft, round and bulged \\
Body shape & Slender in shape, more translucent and less pigmented & Body robust and pigmented \\
Pectoral fin & The pectoral fin spines are relatively larger and thicker & The spines are very faint or absent \\
Genital papilla & Elongated and pointed or conical shape & Large, round and fleshy with reddish vent \\
\hline
\end{tabular}

\section{Induced Breeding}

Induced breeding carried out according to Bhowmick et al., 2000; Chakrabarty and Chakrabarti, 2005; Sarkar et al., 2005. Salmon Gonadotropin releasing Hormone (SGnRHa) named ovaprim was used as the inducing agent for induced breeding of Pabda (Ompok pabda). The SGnRHa elicits the release of stored gonadotropins from the pituitary (Hossain et al., 2012). Both female and male fishes were injected with a constant dose $(1 \mathrm{mg} / \mathrm{kg})$ of S-GnRHa.

\section{Gonadosomatic Index}

The gonads increase to mature as the fish grow. Growth of gonads with the growth of the fish is strongly related and directly proportional. GSI gradually develops till the enlargement of gonads into maturing. Gonadosomatic index (GSI) was determined following the equation of Parameshwaran (Parameshwaran et al., 1971):

$$
\text { GSI }=\frac{\text { Weight of gonad }}{\text { weight of body }} \times 100
$$

\section{Fecundity}

The fecundity is closely associated with the life history and community structure or fish population dynamics of fish (Kapoor and Khanna, 2004). Usually fecundity is defined as the number of developing eggs found in the female just before spawning (Bagenal, 1978). The fecundity of the fish was observed gravimetrically. The external connective tissues on the surface of the ovaries were carefully detached to estimate fecundity. Blotting paper was used to extract the moisture from the ovaries. Ovary weight was recorded with fine electronic balance. The fecundity of the studied fish was calculated following the formula of Le Cren (1951):

Fecundity $=$ (number of eggs in the sample $x$ weight of gonad) / weight of the sample.

Relationship of fecundity with different body measurements such as body length, body weight was moved into log and least squares regression analysis (Bagenal, 1978):

$$
\log F=\log a+b \log X,
$$

Where, $\quad \mathrm{F}=$ Clutch size (fecundity); $\mathrm{X}=$ Length/Weight; $\mathrm{a}=$ Regression constant, $\mathrm{b}=$ Regression coefficient.

\section{Calculation of Fertilization Rate}

Total number of eggs and rate of fertilization were calculated one hour after spawning by direct counting method. After two hours of fertilization, the transparent eggs were considered as fertilized eggs whereas, the opaque eggs were considered as dead eggs. The fertilization rate was estimated according to following formula (Muir and Robert, 1985):

$$
\text { Fertilization rate }(\%)=\frac{\text { No.of fertilized eggs }}{\text { Total no of eggs }} \times 100
$$

\section{Calculation of Hatching Rate}

Hatchlings were counted by naked eyes. The hatching rate was determined by following formula:

$$
\begin{gathered}
\text { Hatching rate }(\%)=\frac{\text { No.of hatchlings }}{\text { Total no.of eggs }} \times 100 \text { (Islam et al., } \\
\text { 2011, Roy et al., 2011) }
\end{gathered}
$$

\section{Calculation of Survival Rate}

Survival rate was calculated just after the hatching. The number of hatchlings counted. The survival rate was determined by following formula (Roy et al., 2019):

$$
\text { Survival rate }(\%)=\frac{\text { No.of hatchlings survive }}{\text { Total no.of eggs }} \times 100
$$

\section{Measurement of Larvae}

All morphological measurements of larvae following the method of Rahman et al. (2004) and McEdward et al. (1984) with slight modification. When hatching was completed, the observations were continued at every $6 \mathrm{~h}$ for the first day and thereafter at every 12 hours interval to study the each development stage, samples are collected from the hapa and rearing cistern. Larvae were stored in $10 \%$ formalin-water and were concentrated by settling of bottom of a vial. Larvae were put under an elevated cover slip on a microscope slide and finally measured by an electronic microscope (Optica) using a presetting objective micrometer and took images by Euromax camera (CMEX 10, 65 DC $10000 C)$ with the magnification of $10 X S$. 


\section{Fish Sampling, Estimation of Growth}

Fish sampling is an important part to estimate different growth parameters. More than 100 fish were sampled fortnightly by using a seine net. Individual fish were measured in terms of length $(\mathrm{cm})$ and weight $(\mathrm{g})$ using a measuring scale and a portable electronic balance. The weight of each fish was measured separately in order to determine the health and productivity of the fish. Growth in terms of weight, average daily gain (ADG), specific growth rate (SGR) and mean values $( \pm S D)$ for each parameter were computed. ADG was calculated according to De Silva (1989). SGR calculated according to Brown (1957) and Ricker (1975).

Average daily gain, ADG = (Final weight W2- Initial weightW1)/Age (days)

The length-weight relationship was estimated using the linear form of the formula by Le Cren (1951),

\section{$\mathrm{W}=\mathrm{a} \times \mathrm{Lb}$}

(Where, $W=$ weight of the fish in $g$; $L=$ length of the fish in $\mathrm{mm}$ and ' $a$ ' and ' $b$ ' are constants) The equation has been transformed into the following logarithmic form: $\log W=\log a+b \log L$ and the values of ' $a$ ' and ' $b$ ' were calculated analytically.

\section{Statistical Analysis}

MS excel was used to perform this statistical analysis. The significant $(P<0.05)$ level was tested following Duncan's test using IBM SPSS statistics software, version 20. To tabulate the results, simple arithmetical tools such as average, range, percentage, and so on were used. A one-way analysis of variance (ANOVA) was performed to evaluate the significance $(P<0.05)$ level of hormonal treatments. Regression equations of those relations were established. Coefficient of correlation ( $r$ ) and regression co-efficient (b) were also determined.

\section{Results}

\section{Sex Ratio}

Among the 365 specimens of $O$. pabda studied, 147 were male and 218 were female (Table 2). The overall male to female sex ratio was observed to be 1:1.48. Female ascendency on male in the population of this fish species have reported by Banik et al. (2012).

\section{Length and Age at First Maturity}

The mature ovaries and testes in relation to length was observed. Males had a minimum length of $16.6 \mathrm{~cm}$ and females had a minimum length of $16.8 \mathrm{~cm}$ during sexual maturity. According to Banik et al. (2012), the male and female of $O$. pabda reach maturity at $16.3 \mathrm{~cm}$ and $17 \mathrm{~cm}$ in length respectively.

\section{Gonado-somatic Index of O. pabda}

The GSI found in the present study were ranged from 2.93 to 4.77 with the mean of $3.77 \pm 0.60$ during the study period (Table 3 ). The highest and the lowest GSI values were in May and April respectively. The GSI values differed significantly $(P<0.05)$ with the body length and weight of fish. Some researchers used total body weight to measure GSI of fishes, such as the cardinal fish Apogon lineatus (Kume et al., 2000), while Brown-Peterson et al. (2001) and Brown-Peterson and Warren (2001) used net weight and omitted the gonad weight in their assessments.

\section{Fecundity}

Fecundity refers to egg-laying ability of fish or the amount of mature or ripe eggs released by a fish in a single spawning or breeding season. The fecundity of O. pabda in the present study was ranged from 5675 to 19626 with the mean of $12503 \pm 4192$ for the corresponding length $21.23 \pm 1.71$, body weight $111.12 \pm 7.6$ and gonad weight $4.19 \pm 0.87$ (Table 3). Islam

Table 2. Variations in Sex ratio of male and female $O$. pabda during study period.

\begin{tabular}{|c|c|c|c|c|c|c|c|c|c|}
\hline \multirow{2}{*}{ Months } & \multirow{2}{*}{ No. of fish } & \multicolumn{2}{|c|}{ Male } & \multicolumn{2}{|c|}{ Female } & \multirow{2}{*}{ Ratio } & \multirow{2}{*}{$P$} & \multirow{2}{*}{$\mathrm{X}^{2}$} & \multirow{2}{*}{ Significance } \\
\hline & & No & Percent & No & Percent & & & & \\
\hline February & 50 & 22 & 44.00 & 28 & 56.00 & $1: 1.27$ & 0.396 & 0.72 & Insignificant \\
\hline March 1st & 40 & 18 & 45.00 & 22 & 55.00 & 1: 1.22 & 0.527 & 0.40 & Insignificant \\
\hline March last & 54 & 24 & 44.44 & 30 & 55.56 & 1: 1.25 & 0.414 & 0.67 & Insignificant \\
\hline April & 56 & 22 & 39.29 & 34 & 60.71 & 1: 1.55 & 0.109 & 2.57 & Insignificant \\
\hline May & 60 & 20 & 33.33 & 40 & 66.67 & 1: 2.00 & 0.009 & 6.67 & Significant** \\
\hline June & 40 & 16 & 40.00 & 24 & 60.00 & $1: 1.50$ & 0.206 & 1.60 & Insignificant \\
\hline July & 65 & 25 & 38.46 & 40 & 61.54 & 1: 1.60 & 0.063 & 3.46 & Insignificant \\
\hline Overall & 365 & 147 & 40.27 & 218 & 59.73 & 1: 1.48 & 0.0002 & 13.81 & Significant** \\
\hline
\end{tabular}

$\mathrm{P}=\mathrm{p}$-value, $\chi^{2}=$ Calculated Chi-square value, ${ }^{* *}=$ Significant at $1 \%$ level, ${ }^{*}=$ Significant at $5 \%$ level.

At $1 \%$ level of significance, $\alpha=0.01$

At $5 \%$ level of significance, $\alpha=0.05$ 
Table 3. Showing the Fecundity and GSI of 20 gravid female Ompok pabda (Hamilton, 1822).

\begin{tabular}{lccccc}
\hline SL. & Total Length $(\mathrm{cm})$ & Body Weight $(\mathrm{g})$ & Gonad Weight $(\mathrm{g})$ & Fecundity & GSI \\
\hline 1. & 16.8 & 98.7 & 3.08 & 5675 & 3.12 \\
2. & 18.5 & 95.4 & 2.92 & 6360 & 3.06 \\
3. & 19.4 & 97.2 & 3.15 & 7020 & 3.24 \\
4. & 100.1 & 3.06 & 7200 & 3.06 \\
5. & 111.5 & 3.27 & 8600 & 2.93 \\
6. & 19.5 & 105.2 & 3.62 & 10220 & 3.44 \\
7. & 117.4 & 3.71 & 11750 & 3.16 \\
8. & 20.4 & 112.05 & 3.67 & 10610 & 3.28 \\
9. & 20.8 & 114.78 & 3.84 & 12708 & 3.35 \\
10. & 112.3 & 4.01 & 11025 & 3.57 \\
11. & 21.6 & 115.6 & 4.11 & 12526 & 3.56 \\
12. & 113.7 & 5.03 & 15225 & 4.42 \\
13. & 21.8 & 119.7 & 4.86 & 14847 & 4.06 \\
14. & 21.1 & 115.6 & 5.13 & 12505 & 4.44 \\
15. & 21.8 & 113.28 & 4.98 & 15771 & 4.40 \\
16. & 22.3 & 113.15 & 5.01 & 16479 & 4.43 \\
17. & 22.0 & 119.93 & 5.72 & 18088 & 4.77 \\
18. & 22.8 & 112.6 & 4.67 & 15465 & 4.15 \\
19. & 22.9 & 118.8 & 4.87 & 19626 & 4.10 \\
20. & 23.5 & 115.6 & 5.18 & 18360 & 4.48 \\
Mean \pm SD & 22.8 & $111.12 \pm 7.6$ & $4.19 \pm 0.87$ & $12503 \pm 4192$ & $3.77 \pm 0.60$ \\
\hline
\end{tabular}

Table 4. Measurement of different stage of embryonic and larval development.

\begin{tabular}{lc}
\hline Larval stage & Measured Length $(\mathrm{mm})$ \\
\hline 0 hour & $1.5 \mathrm{~mm}$ \\
6 hours & $2.6 \mathrm{~mm}$ \\
12 hours & $4 \mathrm{~mm}$ \\
24 hours & $4.3 \mathrm{~mm}$ \\
36 hours & $4.6 \mathrm{~mm}$ \\
48 hours & $4.9 \mathrm{~mm}$ \\
6 hours & $5.2 \mathrm{~mm}$ \\
72 hours & $6 \mathrm{~mm}$ \\
7 days & $7.5 \mathrm{~mm}$ \\
14 days & $3.2 \mathrm{~cm}$ \\
\hline
\end{tabular}

Table 5. Different parameters and observed values of $O$. pabda during the study period.

\begin{tabular}{lccc}
\hline Sl. & Parameters & Observed values (Mean \pm SD) & Significance \\
\hline 1. & Initial length $(\mathrm{cm})$ & $3.57 \pm 0.65$ & NS \\
2. & Initial body weight $(\mathrm{g})$ & $1.60 \pm 0.43$ & NS \\
3. & Final length $(\mathrm{cm})$ & $21.22 \pm 1.84$ & NS \\
4. & Final body weight (g) & $111.12 \pm 6.83$ & NS \\
5. & Gonad weight (g) & $4.19 \pm 0.87$ & NS \\
6. & GSI & $3.77 \pm 0.6$ & NS \\
7. & Fecundity & $12503 \pm 4192$ & NS \\
8. & Fertilization rate (\%) & $84.46 \pm 4.11$ & NS \\
9. & Hatching rate (\%) & $71.20 \pm 1.69$ & NS \\
10. & Survival rate (\%) & $60.40 \pm 0.59$ & NS \\
11. & SGR & $2.85 \pm 0.18$ & NS \\
12. & ADG & $0.73 \pm 0.05$ & \\
\hline
\end{tabular}

NS= Not significant

(2011) observed the fecundity of $O$. pabda ranged from $15560 \pm 185$ to $17369 \pm 213$ during June to August.

\section{Embryonic and Larval Development}

The present observations on embryonic and larval development of Ompok pabda (Table 4 and Fig 2) were more or less similar to those reported by Sarma et al., 2012; Chakrabarty and Chakrabarti, 2005. Different length was observed in Ompok pabda through different hours and days, which given table 5 .

Formation of embryo and differentiation of embryo into larva closely observed during the experiment. Movement of developing embryo observed at 12-14 hours while Chakrabarti et al. (2008) observed it at 14 hours. The caudal region of the embryo became elongated and active within the egg membrane at 16-18 hours. In Ompok pabda, vigorous thrashing movements 
of the embryo were noticeable in 22 hours (Chakrabarti et al., 2008). The hatchlings were yellowish black in colour and measured $4.3 \mathrm{~mm}$ in length. $M$. montanus hatchlings reached $3.0 \pm 0.1 \mathrm{~mm}$ in length when they were newly hatched (Arockiaraj et al., 2003).

\section{Fertilization Rate (\%), Hatching Rate (\%) and Survival Rate (\%)}

The fertilization rate was calculated monthly. The number of fertilized eggs in each bowl was counted. The fertilization rate was $84.46 \pm 4.11 \%$ (Table 5). The number of spawn/larvae in each bowl was counted. The hatching rate was $71.20 \pm 1.69 \%$. In case of survival rate, the number of fry in each bowl was counted. The survival rate was $60.40 \pm 0.59 \%$. However, survival and growth of fry depends on stocking densities, type and quality of supplementary feeds (Debnath et al., 2016).

\section{Growth Parameters}

To assess the growth performance, the mean initial weight, final weight, average daily weight gain, specific growth rate (SGR\%/day) of fishes were recorded during the study period and summarized in table 5 .

\section{Length-Weight, Fecundity-Length, Fecundity-Body Weight and Fecundity-Gonad Weight Relationship}

The scattered diagram obtained for the total length and body weight, fecundity and total length, fecundity and body weight and fecundity with gonad weight relationship shows a perfect correlation. The body weight $(\mathrm{W})$ of the fish was plotted against their total length (L), fecundity was plotted against total length, body weight and gonad weight on arithmetic and logarithmic scales and shows the regression to be positive as the correlation. Calculating the values of regression co-efficient, intercept and co-efficient of correlation, the regression equation of total length on body weight, fecundity on total length, fecundity on body weight and fecundity on gonad weight was established for the fish (Table 6; Fig 3, 4, 5 and 6).

\section{Discussions}

Sarkar et al. (2005), Chakrabarty, Chakrabarty and Mondal (2006) successfully spawned O. pabda in captivity. The sex ratio in a population can change from year to year (Nikolsky, 1963) and it is usually similar in most of the fish species. However, the sex ratio of $O$. pabda showed a predominance of female, which is consistent with $M$ gulio (Islam et al., 2008), O pabda (Gupta et al., 2014). For different length groups and different months, the Chi-square test was used to assess the relative abundance of males and females to avoid theoretical 1:1 ratio on null hypothesis (Oymak et al., 2001). There were only few males and females with mature gonads in the length group of $16-17 \mathrm{~cm}$ in size observed. 0 . pabda reach matureness at the end of first year of its life cycle and males become matured earlier than females reported by Parameswaran et al. (1971), Chakrabarty and Chakrabarti (2005) Chakrabarty et al. (2007) and Chakrabarti et al. (2009, 2012). Information about gonadal development and the spawning season of a species is essential for determining the spawning frequency of its population, which is significant for its management (Hasan et al., 2018). The maximum GSI recorded in the maximum length group of fishes which is also significant.

Variations in fish fecundity may be influenced by a wide range of factors, including different fish samples, different ponds, water temperatures, feeding, food availability, species differentiation, nutritional resources, and so on (Bagenal, 1978). For Ompok pabda, Purkayastha et al. (2012) recorded fecundity ranged from 80-130 eggs per gm body weight of female, while Banik et al. (2012) reported a range of 2,190-41,552. 0 . pabda has a relative fecundity range of 2,00,000$2,50,000 / \mathrm{kg}$ body weight, according to Chakrabarti et al. (2012). From the above literature, the fecundity calculated in the present study significantly varied. The freshly hatched larva measured 4 to $5.5 \mathrm{~mm}$ in length was thin and translucent, with no mouth or pectoral fin (Fig. 2). There was a distinct eye. There were also signs of maxillary and mandibular barbells. The yolk sac was yellowish green in color and oval in shape. The newly

Table 6. Showing a, b, $r$ and regression equation of total length and body weight, total length and fecundity, body weight and fecundity and fecundity and gonad weight of $O$. pabda

\begin{tabular}{lcccc}
\hline Relationship & $\begin{array}{c}\text { Regression } \\
\text { constant (a) }\end{array}$ & $\begin{array}{c}\text { Regression } \\
\text { coefficient (b) }\end{array}$ & $\begin{array}{c}\text { Coefficient of } \\
\text { correlation( } r)\end{array}$ & Regression equation \\
\hline Total length (L) & -60.62 & 8.01 & $0.98^{* *}$ & W $=-60.62+8.01 \mathrm{~L}$ \\
Body weight (W) & $(-1.30)$ & $(2.52)$ & $\left(0.98^{* *}\right)$ & $(\operatorname{Log~W}=-1.30+2.52 \mathrm{Log} \mathrm{L})$ \\
Total length (L) Fecundity & -34874 & 2231.6 & $0.91^{* *}$ & $\mathrm{~F}=-34874+2231.6 \mathrm{~L}$ \\
(F) & $(-1.36)$ & $(4.10)$ & $\left(0.94^{* *}\right)$ & $(\log \mathrm{F}=-1.36+4.10 \mathrm{Log} \mathrm{L})$ \\
Body weight (W) & -38000 & 454.45 & $0.82^{* *}$ & $\mathrm{~F}=-38000+454.45 \mathrm{~W}$ \\
Fecundity (F) & $(-5.30)$ & $(4.58)$ & $\left(0.88^{* *}\right)$ & $(\operatorname{Log~F}=-5.30+4.58 \mathrm{Log} \mathrm{W})$ \\
Fecundity (F) & -6105 & 4436.3 & $0.92^{* *}$ & $\mathrm{~F}=-6105+4436.3 \mathrm{G}$ \\
Gonad weight (G) & $(3.07)$ & $(1.63)$ & $\left(0.93^{* *}\right)$ & $(\log \mathrm{F}=3.07+1.63 \mathrm{Log} \mathrm{G})$ \\
\hline
\end{tabular}

** indicate highly significant at $1 \%$ level of significance

(If $\mathrm{p}$-value $<0.01$, then we reject our null hypothesis at $1 \%$ level of significance and conclude that our test is highly significant) 


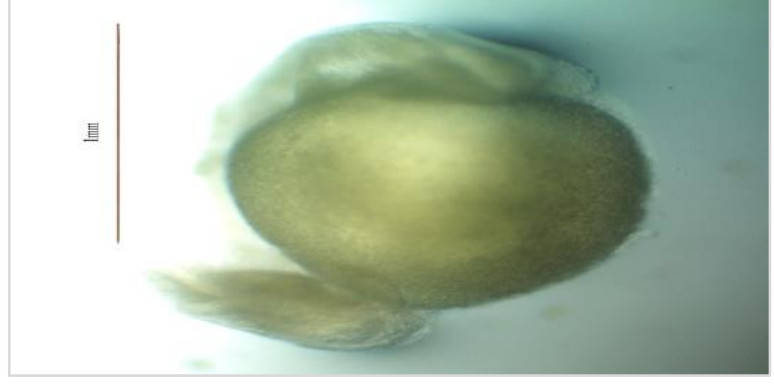

A

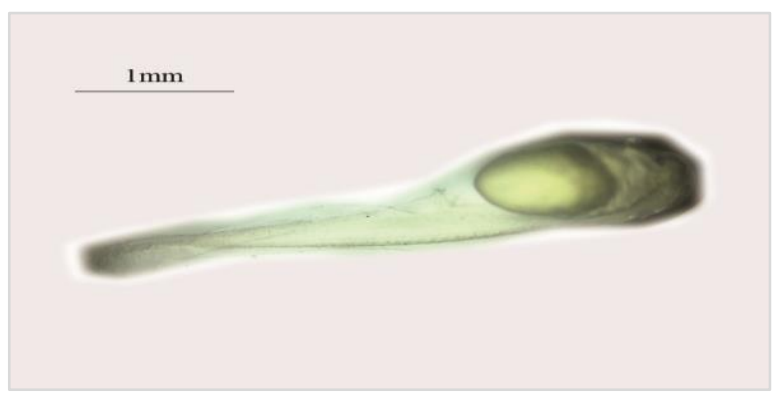

C

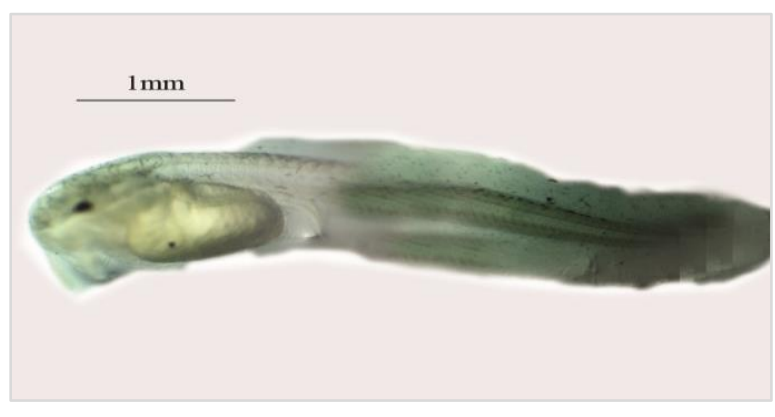

E

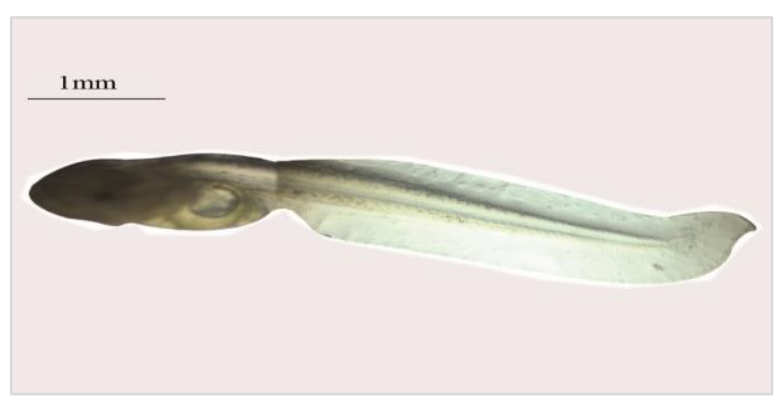

G

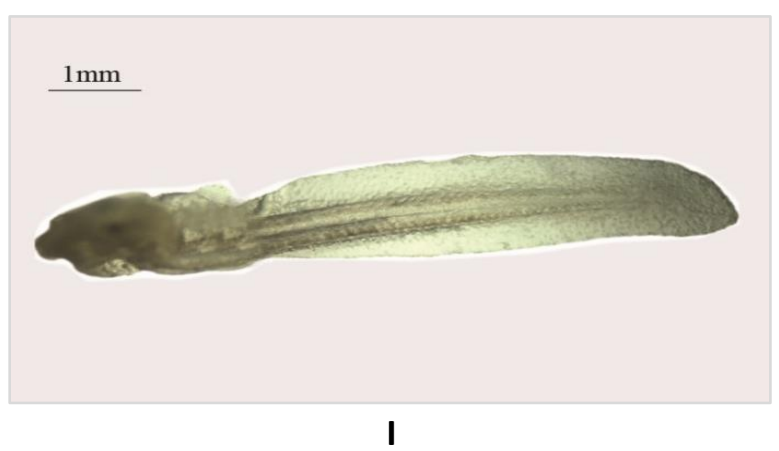

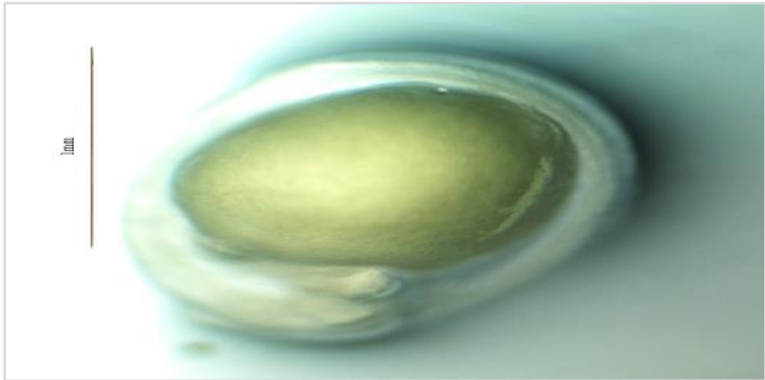

B

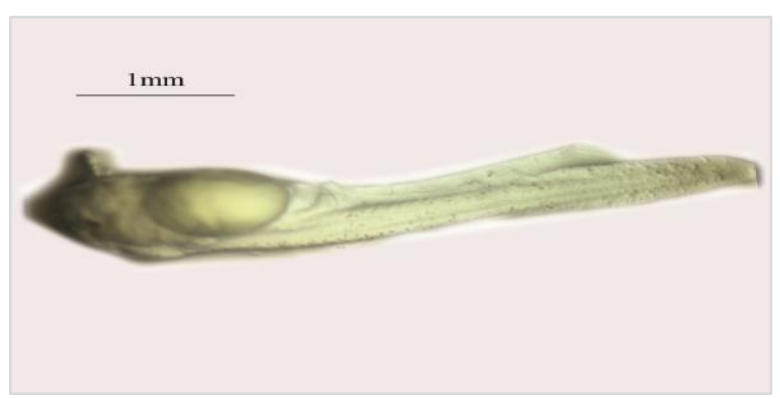

D

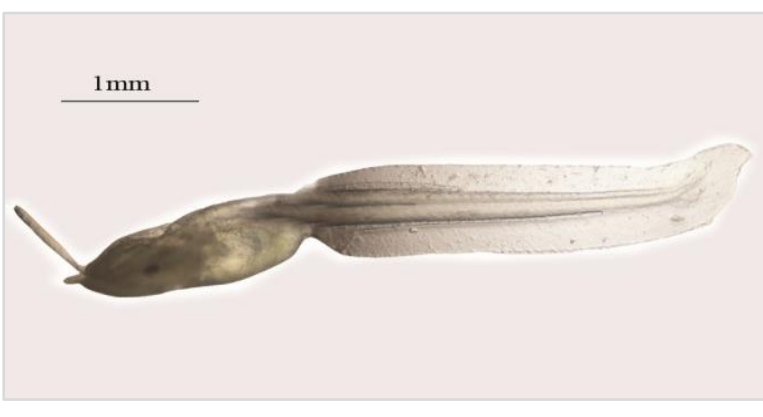

$\mathbf{F}$

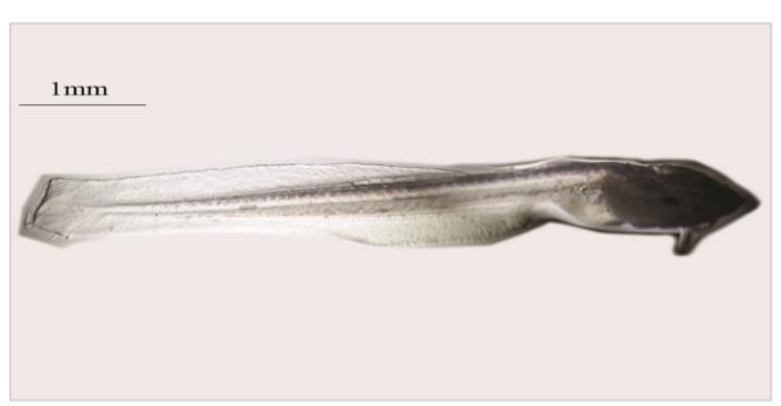

H

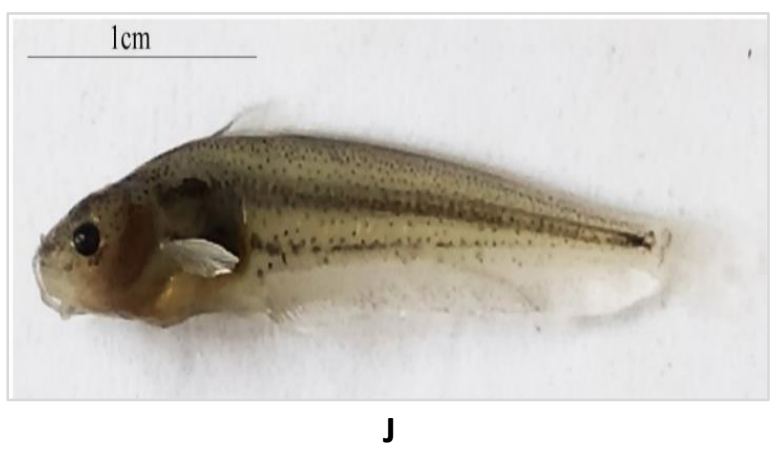

Figure 2. A. 0-hour larvae; B. 6 hours larvae; C. 12 hours larvae; D. 24 hours larvae; E. 36 hours larvae. F. 48 hours larvae; G. 60 hours larvae; H. 72 hours larvae; I.7days larvae; J. 14 days larvae 


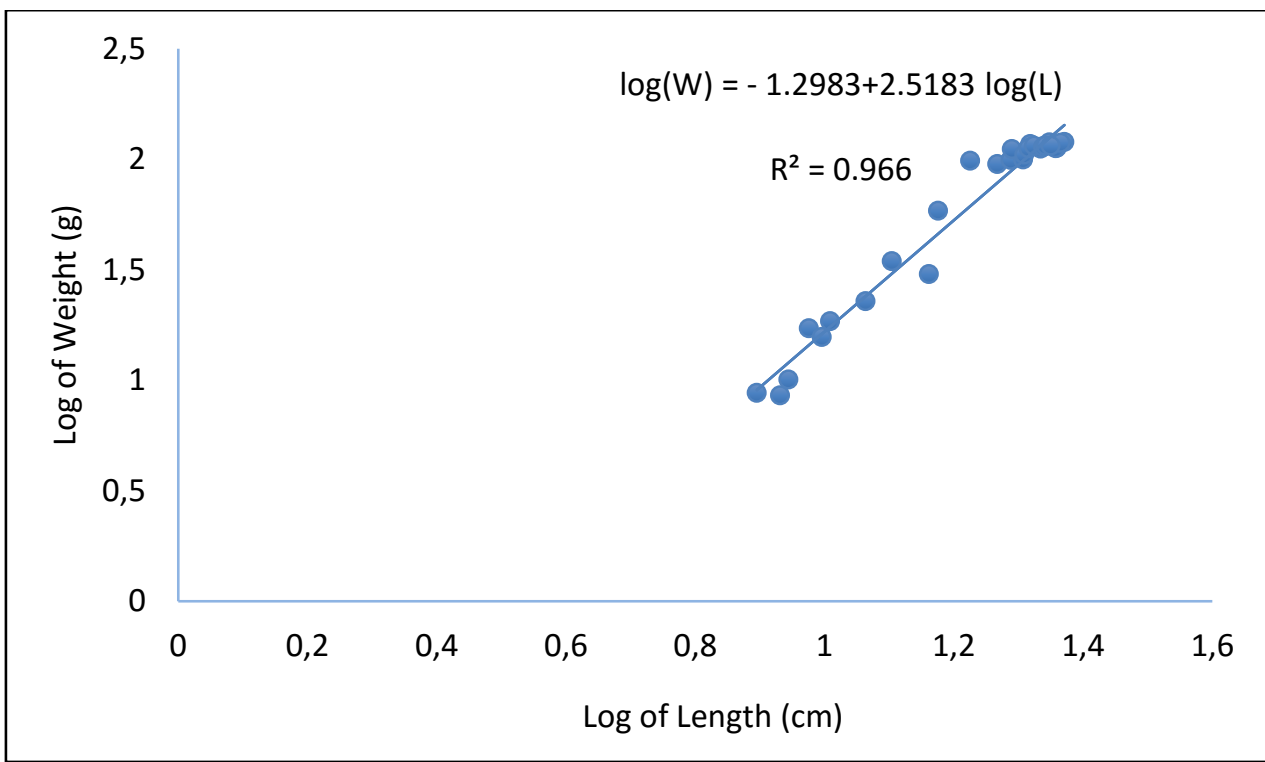

Figure 3. Regression curve showing the Length-weight relationship of $O$. pabda

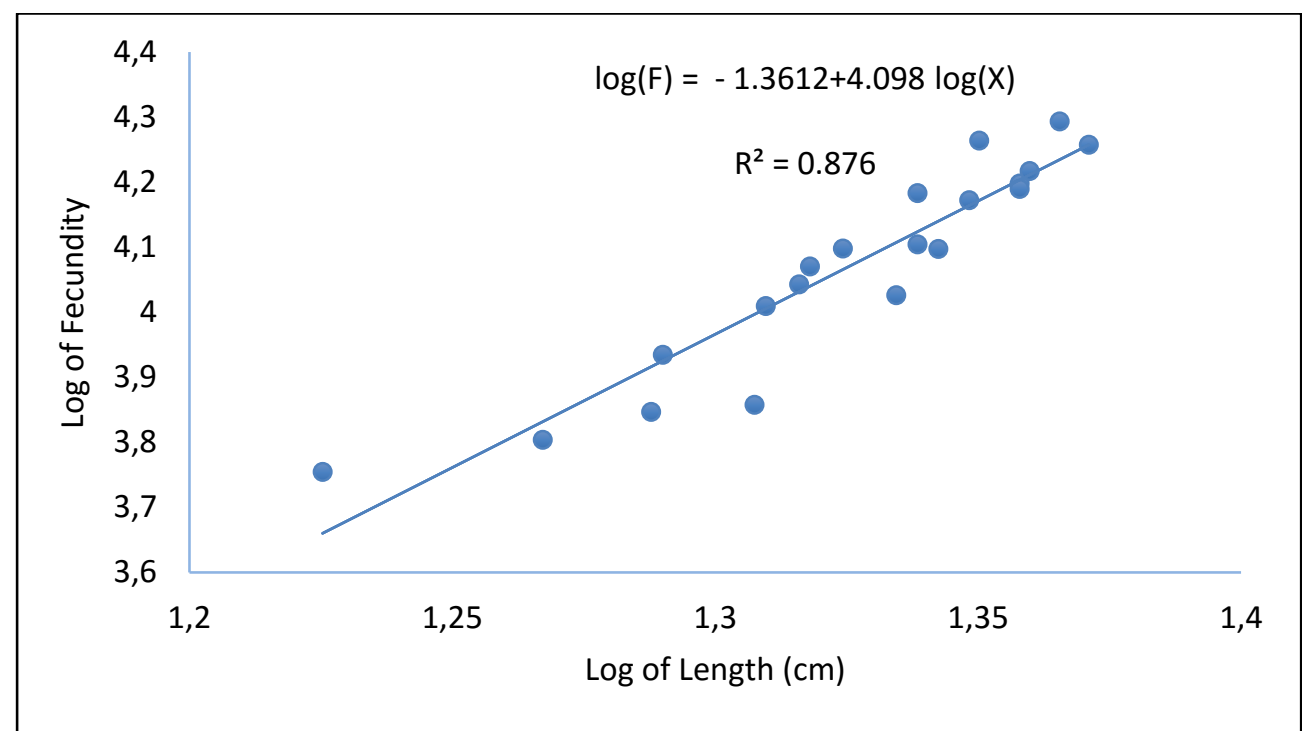

Figure 4. Regression curve showing the Fecundity- length relationship of $O$. pabda

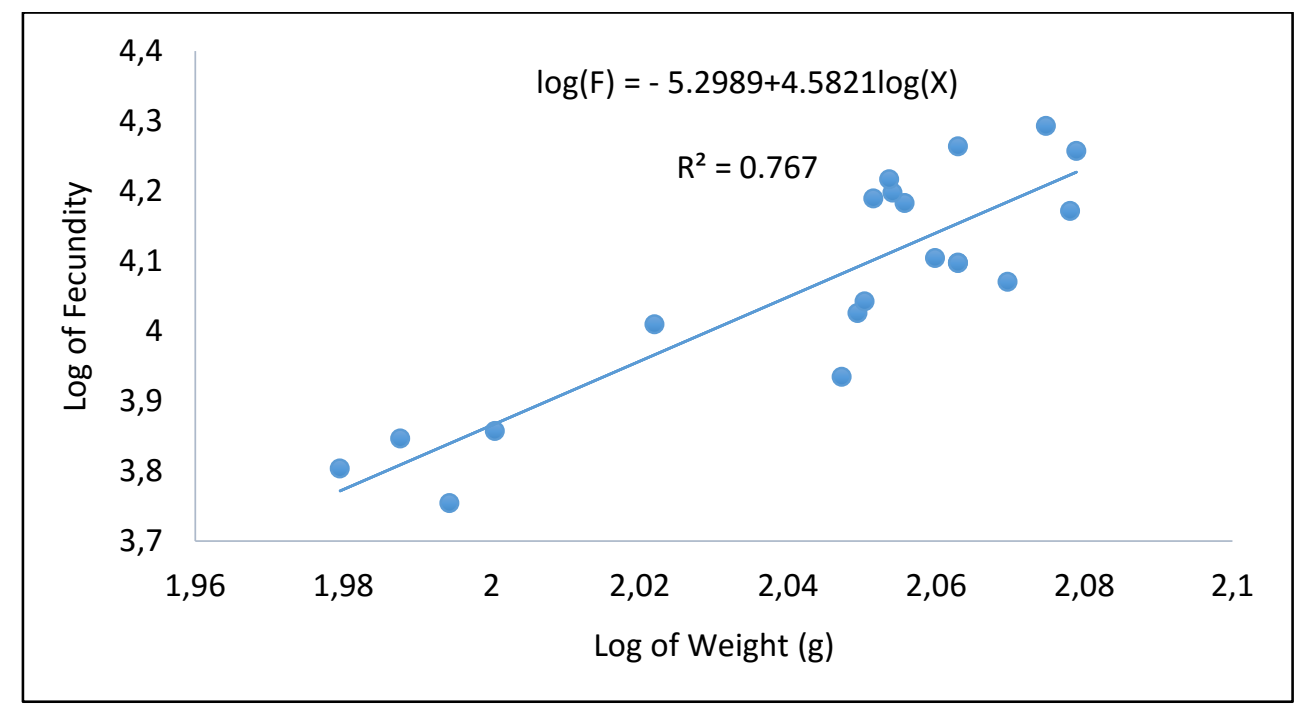

Figure 5. Regression curve showing the Fecundity-weight relationship of $O$. pabda 


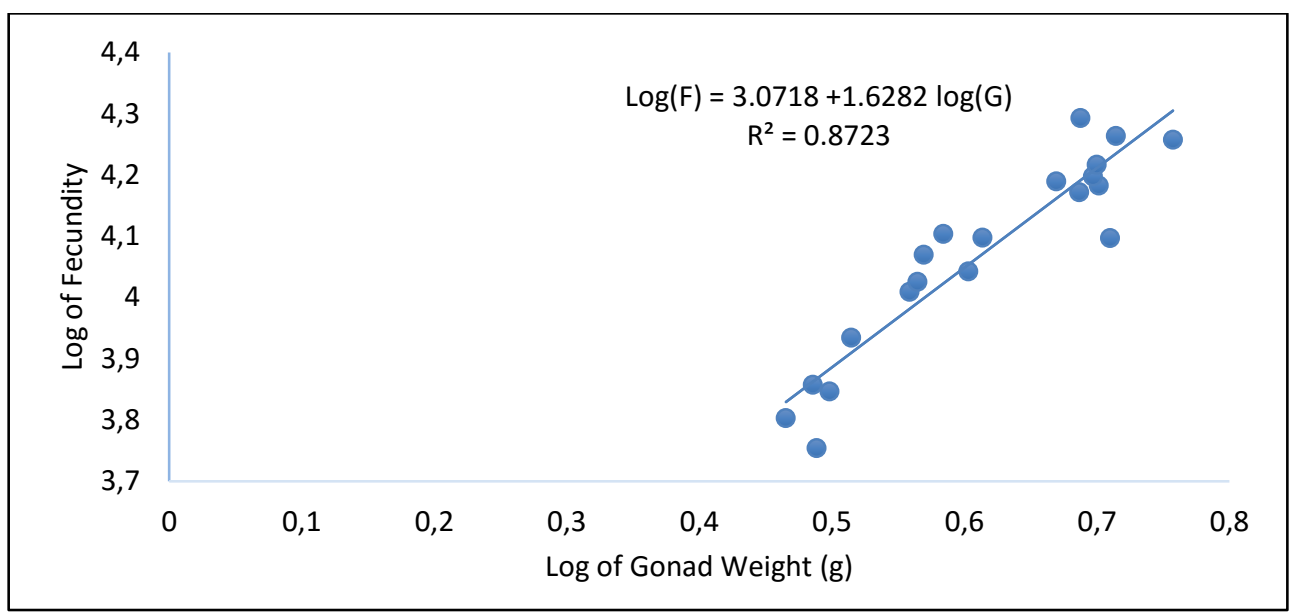

Figure 6. Regression curve showing the Fecundity- gonad weight relationship of $O$. pabda

hatched larvae of $H$. fossilis measured $2.5 \pm 0.2 \mathrm{~mm}$ in length and were translucent and faintly brown in colour (Puvaneswari et al., 2009). Mukherjee et al. (2002) reported the length of 5-6 $\mathrm{mm}$ in Ompok pabo, while Rahman et al. (2004) reported 2.59 to $2.62 \mathrm{~mm}$ in $M$. cavasius.

The fertilization rate found in $O$ pabda is similar to Purkayastha et al. (2012) who reported the fertilization rate of $65.1-75.5 \%$ using different dosage of ovatid and Hossain et al. (2017) recorded as $66.20 \%, 91.00 \%$ and $77.00 \%$ with the three treatments of $\mathrm{T} 1, \mathrm{~T} 2$ and $\mathrm{T} 3$, respectively. The hatching rate of 0 . pabda was estimated to range from $45 \%$ to $60.5 \%$ when treated with ovatid doses of $0.3-0.6 \mathrm{ml} / \mathrm{kg}$ body weight of fish by Purkayastha et al. (2012) which differs slightly from the current research. However, Hossain et al. (2017) recorded the hatching rates $78.40 \%, 90.80 \%$, and $83.80 \%$, in T1, T2 and T3, respectively which supports the present findings. Hossain et al. (2017) recorded the survival rate of 0 . pabda in three experiment were $46.20 \%, 76.60 \%$ and $53.60 \%$ respectively which is also almost similar to the present findings.

Different relationship such as fecundity - total length and fecundity - total body weight shows the affinity with the findings of Islam and Das (2006) for $M$. cavasius, Gupta et al. (2014) for O. pabda. The relationship between gonad weight and fecundity was found to be the most significant $(p<0.01) r=0.92$. This relationship is similar with other findings for $M$. cavasius (Islam and Das, 2006). Fecundity was found to be positively correlated with total length $\left(r^{2}=0.85\right)$, total weight $\left(r^{2}=0.68\right)$, and ovary weight $\left(r^{2}=0.79\right)$ in Arius gagora (Rahman et al., 2020), which supports the current findings.

\section{Conclusion}

The findings of the research will provide useful baseline information of Ompok pabda in Bangladesh. The growth pattern indicated isometric growth for the species. Moreover, information on sex-ratio, length at first maturity, gonado-somatic index fecundity and larval development are observed in this experiment are very significant information regarding to commercial culture and production of this species. Fertilization rate and hatching rate were satisfactory while the survival rate is required to maximize through proper management during captive culture of $O$ pabda. Finally, it can be concluded that further studies are needed to gather more information on biology of $O$. pabda which will be helpful to conserve this species and to continue its fishery for long run.

\section{Availability of Data and Materials}

The data used to support the findings of this study are available from the corresponding author upon reasonable request.

\section{Ethical Statement}

Not applicable.

\section{Funding Information}

This research work partially supported by the grants from Jagannath University, Dhaka, Bangladesh.

\section{Author Contribution}

Dulon Roy and Gulashan Ara Latifa conceived and designed the experiments; Ashish Kumar Sarker and Abu Musa Mohammad Khairul Abedin performed the experiments; Ashish Kumar Sarker, Smita Sarker, Kazi Nahida Begum and Abu Musa Mohammad Khairul Abedin analyzed the data; Dulon Roy wrote the paper. All authors read and approved the final manuscript.

\section{Conflict of Interest}

The authors declare that they have no known competing financial interests or personal relationships that could have appeared to influence the work reported in this paper. 


\section{Acknowledgements}

The authors would like to express their sincere gratitude to the Deshbandhu Matsya Hatchery and Nursury, Shombhugonj, Mymensingh, Bangladesh for providing all technical assistance.

\section{References}

Akhteruzzaman, M., Kohinoor, A.H.M., Shah, M.S., Hussain, M.G. (1993). Observation on the induced breeding of silurid catfish, O. pabda (Hamilton) in Bangladesh. Bangladesh Journal of Life Science, 5(1), 71-75.

Al-Amin, A.Q., Alam, G.M., Hassan, C.H. (2012). Analysis of INSHORE Economic. Benefit and Growth through the Proper Uses of the Utility and Scope of Fisheries and Livestock: A Guideline to the MOFL in Bangladesh. Asian Journal of Animal and Veterinary Advances, 7, 477-488.

Arockiaraj, A.J., Haniffa, M.A., Seetharaman, S., Sing, S.P. (2003). Early Development of a Threatened Freshwater Catfish Mystus montanus (Jerdon). Acta Zoologica Taiwanica, 14, 23-32.

Banik, S., Goswami, P., Acharjee, T., Malla, S. (2012). Ompok pabda (Hamilton-Buchanan, 1822): An endangered Catfish of Tripura, India: reproductive physiology related to freshwater lotic environment. Journal of Environment, 1, 45-55.

Bagenal, T.B. (1978). Aspects of fish fecundity. In: Shelby DG (ed) Ecology of Fresh Water Fish Production, 2nd edn. London, Black Well, pp101-135.

Bhowmick, M.L., Mondal, S.C., Chakrabarty, P.P., Das, N.K., Saha, R.N., Ayyappan, S. (2000). Captive breeding and rearing of Ompok pabda. In: Sarkar AG (ed) Fish biodiversity of North East India. NATP Publication, Lucknow, pp. 1-21.

Brown, M.E. (1957). Experimental studies on growth. In: The physiology of fishes. Vol. I, (ed. Brown ME) Academic Press, New York, pp. 36-400.

Brown-Peterson, N.J., and Warren, J.W. (2001). The reproductive biology of spotted sea trout, Cynoscion nebulosus along the Missisippi Gulf Coast. Gulf of Mexico Sciences, 1, 61-73.

Brown-Peterson, N.J., Overstreet, R.M., Lotz, J.M., Franks, J.S. and Burns, K.M. (2001). Reproductive biology of cobia Rachycentron canadum from coastal waters of southern United States. Fisheries Bulletin, 99, 15-28.

CAMP. (1998). Report of the workshop on conservation assessment and management plan (CAMP) for freshwater fishes of India. Zoo outreach organization and NBFGR, Lucknow 156p.

Chakrabarty, N.M., Chakrabarthy, P.P., and Mondal, S.C. (2006). Mass seed production of pabda and their farming- a challenging step for sustainable utilization of vulnerable fish species. Fishing Chimes 26(1), 135-137.

Chakrabarti, N.M., Chakraborti, P.P., Mondal, S.C., Sarangi, N. (2008). Embryonic development of Pabda (Ompak pabda) - with note on its farming. Fishing Chimes, 28(1), 55-59.

Chakrabarti, P.P., Chakrabarty, N.M., Mondal, S.C. (2009). Breeding and seed production of butter catfish, Ompok pabda (Siluridae) at Kalyani Centre of CIFA India. Aquaculture Asia, 14(1), 33-35.

Chakrabarti, P.P., Mondal, S.C., Chattopadhaya, D.N., Mandal, R.N., Paul, B.N., et al. (2012) Pabda- Seed Production \&
Culture. Central Institute of Freshwater Aquaculture, Bhubaneswar.

Chakrabarty, N.M., Chakrabarti, P.P. (2005). Embryonic development and larval rearing of Ompok pabda (Hamilton). Journal of Inland Fish Society India, 37(1), 71 74.

Chakrabarty, N.M., Chakrabarti, P.P., Mondal, S.C. (2006). Mass seed production of pabda and their farming - a challenging step for sustainable utilization of the vulnerable fish species. Fishing Chimes, 26, 133 -135.

Chakrabarty, N.M., Chakrabarti, P.P., Mondal, S.C. (2007). Artificial breeding seed production and rearing of butter fish Ompok pabda-A significant mile stone in technology advancement. Fishing Chimes, 26, 134-136.

Chakraborty, B.K., Mirza, Z.A., Chakraborty, A. (2010). Reproductive cycle of the endangered Pabda Ompok pabda (Hamilton-Buchanan, 1822) in Bangladesh. Asian Fisheries Science, 23, 301-320.

Cortes, E. (2000). Life history patterns and correlations in sharks. Reviews in Fisheries Science, 8, 299-344.

Datta, S., Rahman, M.M., Haque, M.A., Islam, M.M., Mollah, M.F.A. (2003). Chromosomal studies on Ompok pabda (Hamilton). Journal of Biological Science, 3, 460-465.

Debnath, C., Dube, K., Saharan, N., Tiwari, V.K., Datta, M., Sahool, L., Yadav, G.S., Das, P. (2016). Growth and production of endangered Indian butter catfish, Ompok bimaculatus (Bloch) at different stocking densities in earthen ponds. Aquaculture Research, 47, 3265-3275.

De Silva, S.S. (1989). Reducing feed costs in semi- intensive aquaculture systems in the tropics. NAGA, ICLARM Quarterly, 12(4), 6-7.

Dopeikar, H., Keivany, Y. and Shadkhast, M. (2015). Reproductive biology and gonad histology of the Kura barbel, Barbus lacerta (Cyprinidae), in Bibi-Sayyedan River, Tigris basin, Iran. North-Western Journal of Zoology, 11, 163-170.

Gupta, S., Banerjee, S. (2008). Ornamental fish trade in West Bengal. Fishing Chimes, 28, 25-27 \& 38.

Gupta, S., Banerjee, S. (2013). Indigenous ornamental fish trade of West Bengal. Narendra Publishing House, New Delhi, India.

Gupta, B.K., Sarkar, U.K., Bhardwaj, S.K. (2014). Reproductive biology of Indian Silurid catfish Ompok pabda in river Gomti. Journal of Environmental Biology, 35(2), 345-351.

Hasan, T., Hossain, M.D., Mamun, M., Alam. J., Salam, M.A., and Rafiquzzaman, S.M. (2018). Reproductive Biology of Puntius sophore in Bangladesh. Fishes 3(2), 22. https://doi.org/10.3390/fishes3020022.

Hossain, M.B., Rahman, M., Sarwer, G., Ali, Y., Ahamed, F., Rahman, S., Fulanda, B., Rahman, M., Subba, B.R., Hossain, M.Y. (2012). Comparative study of carp Pituitary Gland (PG) extract and Synthetic Hormone Ovaprim used in the induced breeding of Stinging Catfish Heteropneustes fossilis. Our Nature, 10, 89-95.

Hossain, M.S., Ali, M.R., Rahman, M.I., Hasan, A.K.M.M., Iqbal, M.M., and Barman, S.K. (2017). Induced Breeding of Ompok pabda with S-GnRHa. International Journal of Natural Sciences, 6(3), 141-147.

Hussain, A. (2006). Seed production of Ompok pabda (Ham.) in hatchery of C.G. Co-operative Fish Federation. Fishing Chimes, 26, 136-139.

Islam, M.K., and Das, M. (2006). Fecundity of Gulsha Mystus cavasius (Hamilton) from Brahmaputra and Kongsa rivers. Journal of Bangladesh Agriculture University, 4(2), 347-355. 
Islam, M.A., Begum, M., Pal, H.K., Alam, M.J. (2008). Studies on the Gonadosomatic Index and Fecundity of Mystus gulio (Ham.). Progressive Agriculture, 19(2), 161-166.

Islam, S. (2011). Brood rearing and induced breeding of pabda (O. pabda) at BFRI, Mymensingh. Master of Science (MS) in aquaculture department. $67 \mathrm{p}$.

Islam, S., Shah, S., Rahi, L. (2011). Study of fecundity and induced breeding of Mystus vittatus. Bangladesh J. Zool., 39, 205-212.

IUCN Bangladesh (2000). Red book of threatened fishes of Bangladesh. IUCN. The World Conservation Union.

Jayaram, K.C. (2009). Catfishes of India. Narendra Publishing House, New Delhi.

Jhingran, A.G., Verma, D.N. (1972). Sexual maturity and spawning of Gudusia chapra (Ham.) in Ganga river system. Proceedings of the Indian National Science Academy, 42(2), 207-224.

Kapoor, B.G., and Khanna, B. (2004). Ichthyology handbook. Springer-Verlag, Berlin.

Kume, G., Yamaguchi, A., Aoki, I., and Taniuchi, T. (2000). Reproductive biology of the cardinal fish Apogon lineatus in Tokyo Bay, Japan. Fisheries Science, 66, 947 954.

Le Cren, E.D. (1951). The length-weight relationship and seasonal cycle in gonad weight and condition in the perch (Perca fluviatilis). Journal of Animal Ecology, 20(2), 201-219.

Mazid, M.A. (2002). Development of fisheries in Bangladesh, Plan and Strategies for Income Generation and Poverty Alleviation. 176 Dhaka: Nasima Mazid, 74 A/2, Kallyanpur Main Road.

Mc edward, L.R. (1984) Morphometric and metabolic analysis of the growth and form of an echinopluteus. Journal of Experimental Marine Biology and Ecology, 82(2-3), 259287.

Mishra, S.S., Acharjee, S.K., Chakraborty, S.K. (2009). Development of tools for assessing conservation categories of siluroid fishes of fresh water and brackish water wetlands of South West Bengal, India. Environ Biol Fishes., 84, 395-407.

Muir, F.J., and Robert, J.R. (1985). Recent advances in aquaculture. Croon Helm, London \& Sydney. Westview Press Boulder, Colorado. p. 2.

Mukherjee, M., Das, S. (2002). Artificial propagation of a siluroid fish Ompok pabda (Ham.). Fishing Chimes, 26(1), 75-77.

Mukherjee, M.A., Praharaj, A., Das, S. (2002). Conservation of endangered fish stocks through artificial propagation and larval rearing technique in West Bengal, India. Aquaculture Asia, 7(2), 8-11.

Mukhopadhyay, T., and Ghosh, S. (2007). Lipid profile and fatty acids composition of two silurid fish eggs. Journal of Oleo Science, 56(8), 399-403.

Nikolsky, G.V. (1963). The ecology of fishes. Academic Press. London and New York. 352p.

Oymak, S.A., Solak, K., Unlu, E. (2001). Some biological characteristics of Silurus triostegus, Heckel, 1843 from Ataturk Dam Lake (Turkey). Turkish Journal of Zoology, 25(2), 139-148.

Parameswaran, S., Selvaraj, C., Radhakrishnan, S. (1971). Notes on the life history and biology of the cat fish Ompok pabda (Hamilton). Journal of Zoological Society India, 23,137-150.
Peña-Mendoza, B., Gómez-Márquez, J.L., Salgado-Ugarte, I.H., and Ramírez-Noguera, D. (2015). Reproductive biology of Oreochromis niloticus (Perciformes: Cichlidae) at Emiliano Zapata dam, Morelos, Mexico. Revista de Biología Tropical, 53 (3-4), 515-522.

Purkayastha, S., Sarma, S., Sarkar, U.K., Lakra, W.S., Gupta, S., and Biswas, S.P. (2012). Captive Breeding of Endangered Ompok pabda with Ovatide. Journal of Applied Aquaculture, 24, 42-48.

Puvaneswari, S., Marimuthu, K., Karuppasamy, R., and Haniffa, M.A. (2009). Early embryonic and larval development of Indian catfish Heterpneustes fossilis. EurAsian Journal of BioSciences, 3, 84-96.

Rahman, M.R., Rahman, M.A., Khan, M.N., Hussain, M.G. (2004). Observation on the embryonic and larval development of silurid catfish, gulsa (Mystus cavasius). Pakistan Journal of Biological Sciences, 7(6), 1070-1075.

Rahman, M.A., Hossain, M.A., Ullah, M.R., Iqbal, M.M. (2020). Reproductive biology of Gagora catfish (Arius gagora) at Meghna river system, Kushiara River, Bangladesh. International Journal of Aquatic Biology, 8(6), 383-395.

Roy, D., Rahaman, M.M., Sarker, A., Maud, A.A., and Rahman, M.M. (2011). Study of the artificial breeding of pond reared thai koi Anabas testudineus (Bloch, 1972) in Bangladesh. Intl. J. BioRes., 10(6), 9-13.

Roy, D., Masud, A.A., Saha, P.K., Kutubuddin, M.M., and Islam, M.M. (2019). Water quality, growth and production performance of stinging catfish Heteropneustes fossilis (Bloch) in cemented tanks with two different stocking densities. Bangladesh Journal of Zoology, 47(1), 107119.

Ricker, W.E. (1975). Computation and interpretation of biological statistics of fish populations. Bulletin of Fisheries Research Board of Canada 191:1-382

Sarkar, U.K., Deepak, P.K., Negi, R.S., Paul, S.K., Singh, S.P. (2005). Captive breeding of an endangered fish Ompok pabda (Hamilton-Buchanan) using different doses of Ovaprim. Journal of Inland Fisheries Society of India, 37(2), 37-42.

Sarma, D., Das, J., Dutta, A., and Goswami, U.C. (2012). Early embryonic and larval development of Ompok pabo with notes on its nursery rearing. European Journal of Experimental Biology, 2 (1), 253-260.

Shafi, M., Quddus, M.M.A. (2001). Bangladesher matsho shampad (Fisheries of Bangladesh) (in Bengali). Kabir Publication, Dhaka, Bangladesh.

Siddiqua, K.A., Islam, M.S., Hossain, M.G., and Ahmed, A.T.A (2000). A histological study of the spermatogenesis in Ompok pabda (Hamilton-Buchanan 1822). Bangladesh Journal of Fisheries Research, 4(2), 185-189.

Siddiqui, K., Choudhury, S.N. (1996). A manual on pond pisciculture. The National Institute of Local Government, Dhaka, Bangladesh.

Solomon, S.G., Okomoda, V.T., Aladi, S.L. (2012). Fish fauna in lower River Niger at Idah in Kogi State. Journal of Agricultural and Veterinary Sciences, 4, 34-37.

Soofiani N.M., Keivany, Y., and Shooshtari, A.M. (2006). Contribution to the biology of the lizardfish, Saurida tumbil (Teleostei: Aulopiformes) from the Persian Gulf. Zoology in the Middle East, 38, 49-56.

Talwar, P.K., Jhingran, A.G. (1991). Inland fishes of India and adjacent countries. Oxford and IBH Publishing Co. Pvt. Ltd. New Delhi, Bombay and Calcutta, India. 